\title{
Pollen evidence from Baode of the northern Loess Plateau of China and strong East Asian summer monsoons during the Early Pliocene
}

\author{
LI XingRu ${ }^{1}$, FANG XiaoMin ${ }^{1,2 *}$, WU FuLi ${ }^{1} \&$ MIAO YunFa ${ }^{1}$ \\ ${ }^{1}$ Laboratory of Tibetan Environment Changes and Land Surface Processes (TEL), Institute of Tibetan Plateau Research, Chinese Academy of \\ Sciences, Beijing 100085, China; \\ ${ }^{2}$ Key Laboratory of Western China's Environmental Systems, Ministry of Education \& College of Resources and Environment, Lanzhou \\ University, Lanzhou 730000, China
}

Received August 10, 2010; accepted October 9, 2010

\begin{abstract}
The red clay eolian sequence on the Chinese Loess Plateau (CLP) is an important archive for paleoclimate change from the late Miocene to Pliocene, and can provide significant information for the controversial problems of East Asian monsoon evolution and its forcing mechanism. In this study, we present a pollen record from Baode, northern CLP. The record shows four stages of paleoecological evolution. From 5.6-4.4 Ma, a forest steppe ecosystem developed under an extremely warm period with high seasonal precipitation. Since 4.4 Ma, a drier episode occurred, which prompted parkland landscapes to develop. During 3.5-3.05 Ma, the environment changed to a rather open steppe ecosystem with a much cooler and drier climate. After 3.05 Ma, the vegetation evolved to forest steppe. Using the percentages of arboreal plants to mirror precipitation, and comparing with other published pollen data from the CLP, we find the existence of S-N directionality of the precipitation change and high percentage of arboreal plants in the entire CLP during the Early Pliocene, which suggest the CLP was characterized by a strong East Asian summer monsoon. The strong summer monsoon corresponds well to the low global ice volume, which may illuminate global climate mechanism for the summer monsoon evolution in the early Pliocene.
\end{abstract}

Chinese Loess Plateau, Pliocene, pollen, East Asian summer monsoon, Baode

Citation: $\quad$ Li X R, Fang X M, Wu F L, et al. Pollen evidence from Baode of the northern Loess Plateau of China and strong East Asian summer monsoons during the Early Pliocene. Chinese Sci Bull, 2011, 56: 64-69, doi: 10.1007/s11434-010-4235-8

The East Asian monsoon (EAM) dominates the climate of much of China and its surrounding areas, and is an important factor for precipitation patterns. The major monsoon precipitation of the Chinese interior regions decreases from the southeast to the northwest direction. Along with decreasing precipitation, the vegetation changes from forest in southeastern China to steppe and ultimately desert in northwestern China. The Chinese Loess Plateau (CLP) is located precisely within the transition zone (Figure 1). Thus, the area is ideally situated for studying the long-term evolution of the monsoon system.

It has been confirmed that the eolian loess-paleosol and red clay sequences on the CLP are an excellent continuous

*Corresponding author (email: fangxm@itpcas.ac.cn) terrestrial archive for understanding EAM evolution [1-3]. The Chinese loess-paleosol alternation was caused by the strengthening and weakening of the East Asian paleomonsoons. Intervals of loess deposition developed during warm-humid interglacial climates, corresponding to strengthened winter monsoons, whereas soil-forming intervals occurred during cool-arid glacial climates, corresponding to strengthened summer monsoons [1-7]. Studies of the underlying red clay sequences show that the EAM commenced at least $8 \mathrm{Ma}$ ago [2], or even earlier at $22 \mathrm{Ma}$ ago [3]. The latter date is supported by land vegetation data [8]. However, there is still much debate about the evolution and forcing mechanism of the EAM. Inorganic proxies, such as coarser grain size, stronger magnetic susceptibility, and higher $\mathrm{Rb} / \mathrm{Sr}$ ratios, all indicate that the continued intensifica- 
tion of East Asian summer and winter monsoons strengthened simultaneously at about 3.6 Ma [2,9]. In addition, the low volume of $\mathrm{C}_{4}$ vegetation indicates the EASM was relatively weak before $\sim 3.6 \mathrm{Ma}$ [9-11]. The above has lead researchers to conclude that the EASM was relatively weak prior to this time. However, the weak summer monsoon before $3.6 \mathrm{Ma}$ corresponds exactly to a period of low ice volume and warm intervals at high latitudes in the Northern Hemisphere [12,13]. This link clearly is inconsistent with the patterns of monsoons and global ice volumes recorded by the loess-paleosol of the Pleistocene. In this study we investigated the evolution of vegetation to evaluate the above problem.

Vegetation is a direct and sensitive indicator for climate change. There are only two studies concerning the red clay sediments, mainly from central and southern parts of the Loess Plateau $[14,15]$. The northern CLP is much more sensitive to climate change. However, the continuous record is sparse. Thus, here we present a continuous pollen record from the Luzigou section of Baode, northern CLP. In addition, by latitudinal comparisons with previously published data, we discuss the evolution of the EASM.

\section{Study area and settings}

The CLP is situated within the transition zone from monsoon to arid regions. Precipitation is a crucial deterministic factor in spatial distribution of the vegetation [16]. Under control of the EAM, there is a strong climatic gradient over the CLP. Over the plateau, the mean annual precipitation decreases from $\sim 650 \mathrm{~mm}$ in the southeast to $\sim 300 \mathrm{~mm}$ in the northwest. The vegetation patterns in this region can mirror precipitation patterns. Broadleaf deciduous forests are dominant to the south of the CLP, and the CLP spans the northwestward transition from steppe to desert [17] (Figure 1).

The Luzigou study section is located in Luzigou Village, Baode County, northern CLP $\left(111^{\circ} 09^{\prime} 32^{\prime \prime} \mathrm{E}, 39^{\circ} 01^{\prime} 01^{\prime \prime} \mathrm{N}\right)$

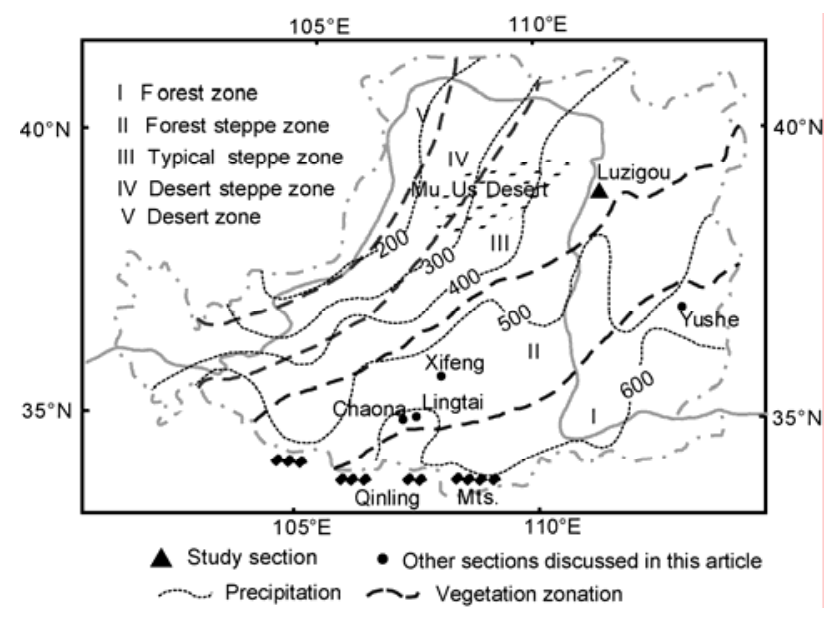

Figure 1 Location of the study area, precipitation and vegetation zonation of the CLP.
(Figure 1). Baode is the representative area where the typical Hipparion fauna was first discovered, and the Baode Red Clay was defined [18,19]. The average annual temperature is $8.8^{\circ} \mathrm{C}$. The mean annual precipitation is about $493.6 \mathrm{~mm}$, concentrated in July and August. The present vegetation is a typical arid steppe, dominated by dwarf xerophil brushwood. The flora is mainly composed of shrubs, such as Hippophae rhamnoides, Spiraea, Ostryopsis davideana, Sanguisorba officinalia, Chrysanthernum indicum, Artemisia sacrorum, Stipa capillata, Thymus mongolicus, Themeda gigantea, Setaria viridis, Zizyphus sativa, and Eragrostis pilosa [20].

Recently, the stratigraphy of the Luzigou red clay section was investigated. The red clay sediments are $\sim 50 \mathrm{~m}$ thick, with a reworked unit between $\sim 8.4-50 \mathrm{~m}$, and typical wind-blown red clay above $8.4 \mathrm{~m}$. The loess strata lie conformably with the red clay. The red clay sequences extend between $\sim 6.6 \mathrm{Ma}$ and $\sim 2.8 \mathrm{Ma}$ [21] (Figure 2).

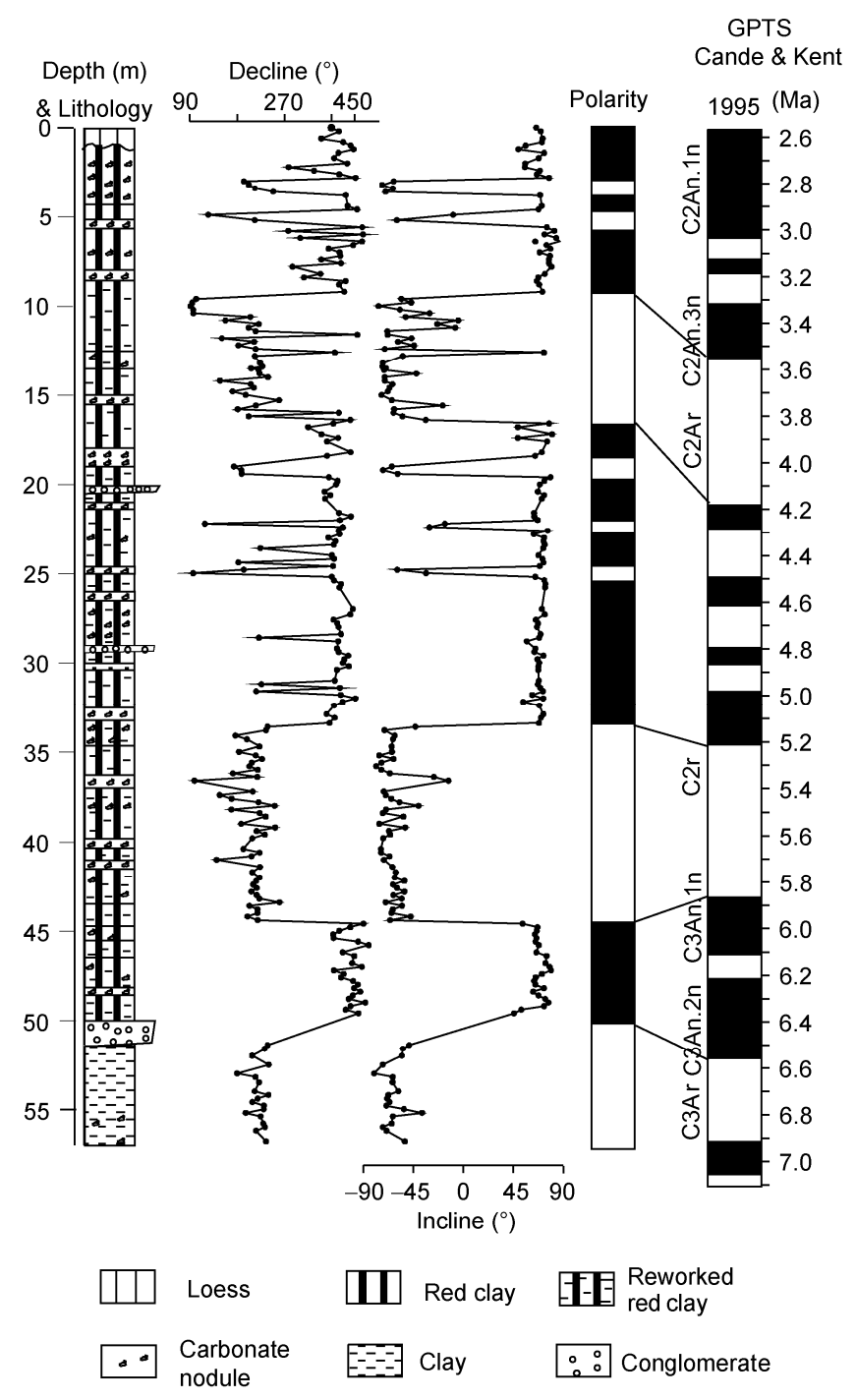

Figure 2 Lithology and polarity of the Luzigou section [21]. 


\section{Materials and methods}

A total of 120 samples were collected for pollen analysis within interval of 30-50 cm. Using previously-tested methods, we extracted pollen grains from the loess-red clay sequences [15,22]. For each sample, we treated $200 \mathrm{~g}$ of sediment with hydrochloric acid and hydrofluoric acid. This procedure removed carbonates and silicates, respectively. We then concentrated the pollen by sieving the remaining material through a $10 \mu \mathrm{m}$ mesh in an ultrasonic bath and discarded the fine fraction. The pollen residue, together with glycerine, was prepared on slides.

\section{Palynological records}

Samples collected below $40 \mathrm{~m}$ depth had little or no pollen. Thus, we focus our discussions of results to the strata above $40 \mathrm{~m}$, with 100 samples in total. More than 100 pollen grains were obtained from 73 samples. The remaining 27 samples contained less than 100 pollen grains.

The collected pollen grains were grouped into 24 families and 32 genera. The arboreal taxa include Pinus, Keteleeria, Betula, Quercus, Ulmus, Zelkova, Rutaceae, Juglans, Rhus, Carpinus, Salix, and Castanea/Castanopsis among others. In addition, scrubby and herbaceous taxa included Artemisia, Chenopodiaceae, Compositae (excluding Artemisia), Gramineae, Nitraria, Ranunculaceae, Cruciferae, and Polygonum.

To synthesize the information and emphasize the palynological trends, we selected 17 major taxa to construct a pollen diagram. In the diagram, the samples that contained less than 100 pollen grains were excluded. According to variations in the abundance of the dominant palynomorph taxa, and nap/ap (aridity index [23]), four ecological zones were identified in our sedimentary record (Figure 3).

Zone I (5.6-4.4 Ma, 40-19 m). In this zone, the arboreal taxa had a significant content $(16 \%-35.8 \%$, average $27.3 \%)$. The broadleaf trees of Betula (3.7\%-14\%) and $U l$ mus $(2.7 \%-14.2 \%)$ were the most common, accompanied by Quercus ( $0-7.4 \%$, average $2.4 \%)$. The coniferous taxa mainly included small amounts of Pinus (average 4\%, with the highest content being $8.0 \%$ ). Other arboreal taxa were Salix, Juglans, and Carpinus with less than 5\% each. There were some subtropical taxa such as Rutaceae, Rhus, Zelkova. The herbaceous taxa were abundant, mainly including arid types, such as Artemisia (24.8\%-56.5\%, average $39.2 \%)$, Chenopodiaceae $(10.5 \%-34.9 \%$, average $21.0 \%)$, and mesophilous Gramineae (10.5\%-35.4\%), along with small amounts of Ephedra and Nitraria, with amounts less than $1 \%$ each. Nap/ap values were between 1.8 and 5.1, with a mean value of 2.85 .

Zone II (4.4-3.5 Ma, 19-8 m). Forest taxa showed slightly decreasing, with an average of $21.5 \%(15.6 \%-$ $30.9 \%$ ). These included Ulmus (average 5.6\%) and Betula (average $4.9 \%$ ). The amounts of Quercus and Salix were low, with average percentages of $2.5 \%$ and $1.6 \%$, respectively. The main needle tree was Pinus (average 3.3\%). The amounts and frequencies of subtropical taxa were low. The percentage of herbaceous taxa increased, with the subdesertic type of Chenopodiaceae averaging 33.6\%, and Gramineae ranged between $3.5 \%-15.8 \%$. Artemisia decreased, and had an average value of $32 \%$. Nap/ap values were between 2.0 and 7.0, with a mean value of 4.23. At the top of this zone, the percentage of Chenopodiaceae was up to $45 \%$. In addition, the arboreal taxa were low in abundance, and subtropical species were not present.

Zone III (3.5-2.8 Ma, 8-1 m). This zone had a considerably high number of herbaceous taxa $(66.1 \%-90.7 \%)$, and the species and amounts of forest taxa were lower (average

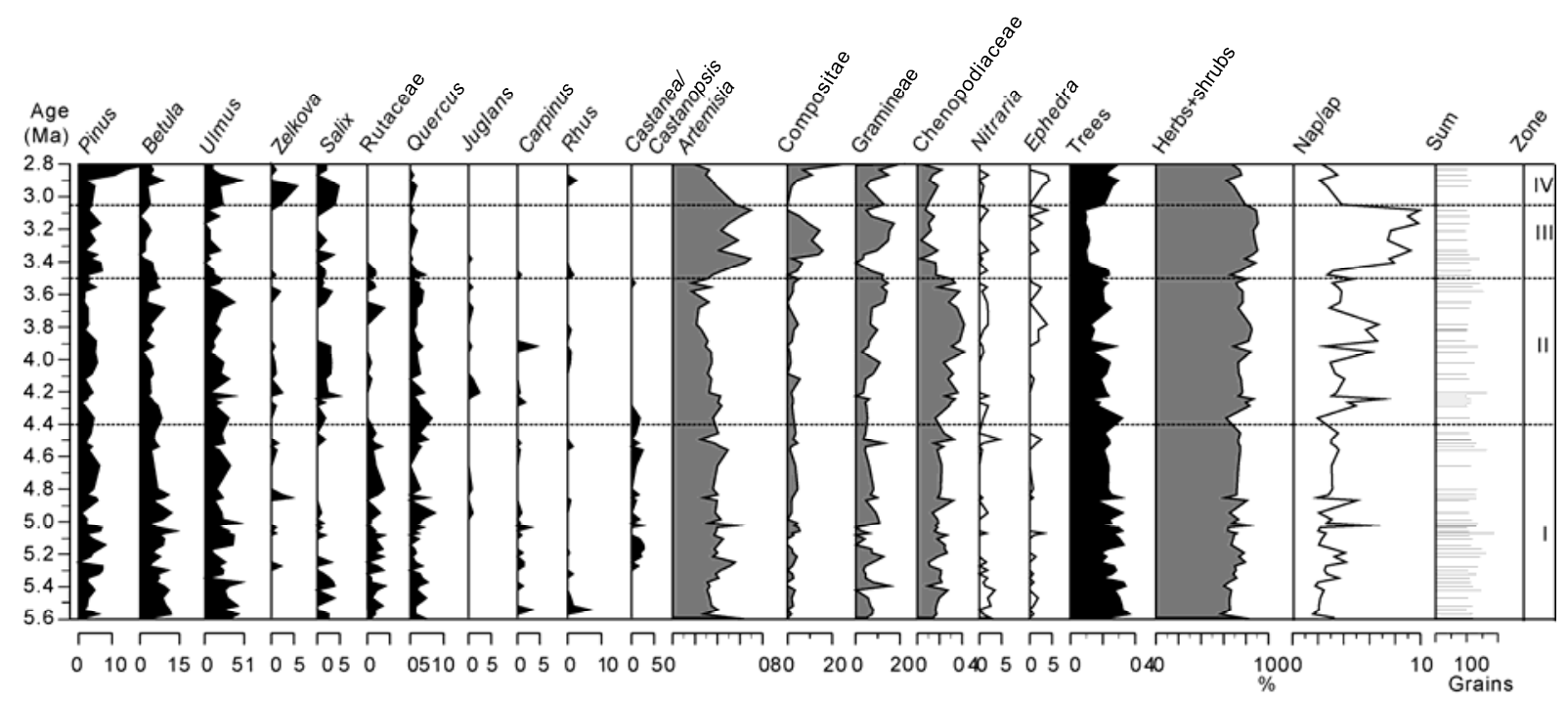

Figure 3 Age, pollen diagram and zones of the Luzigou section. 
$11.4 \%)$. Artemisia increased with an average of $56.9 \%$. The species of Compositae also increased greatly (0-15.7\%). The percentage of Chenopodiaceae decreased to $11.7 \%$. In addition, the forest taxa mainly were made up of Betula, Ulmus and Salix, with mean values of $2.4 \%, 2.3 \%$, and $1.2 \%$, respectively. Juglans and Carpinus decreased in abundance, and subtropical taxa, such as Rutaceae diminished. Nap/ap values were between 7.4 and 9.9, with a mean value of 8.54

Zone IV (3.05-2.8 Ma, 3-1 m). The arboreal taxa (20.8\%$29.7 \%$ ) increased in abundance, with an average of $25.4 \%$, mainly including Pinus (average 9.3\%) and Ulmus (average $6.4 \%$ ). The percentages of Betula and Salix were $4.7 \%, 2.6 \%$, respectively. Juglans and Carpinus were not present. The thermo-humidiphilous subtropical taxa decreased, except for Zelkova, which yielded an average of $1.5 \%$. The nonarboreal taxa were composed of Artemisia, Chenopodiaceae, and Gramineae. Compositae is less than $10 \%$, except for one sample $(24.8 \%)$ at the top of this zone. Nap/ap values were between 2.1 and 3.5, with a mean value of 2.89 .

\section{Discussion}

Studies of the long-term pollen record in the loess-red clay sequence are rare because of the oxidizing environments of loess and red clay deposits. However, with improved laboratory techniques [24-26], it now is possible to effectively extract pollen gains. By taking a large bulk sample, we were able to collect more than 100 grains of pollen from most samples. This amount is statistically powerful for reconstructing paleo-vegetation and paleo-environments.

\subsection{Early-mid Pliocene paleo-vegetation and paleocli- mate evolution}

Within the entire section, the pollen assemblages were relatively stable. Pollen records delineated four stages of paleo-vegetation and paleoclimate evolution. During the time interval of 5.6-4.4 Ma, the pollen assemblages showed relatively high percentages of arboreal taxa (15\%-36\%), mainly including the temperate and warm-temperate deciduous Betula, Ulmus, Quercus. The study of pollen-climate response surface indicated that Betula and Quercus were very sensitive to the humidity [27-29]. It is important to emphasize the development of subtropical thermophilous broadleaf trees, such as Rutaceae and Rhus. The herbaceous taxa were most prevalent; the drought-enduring Artemisia and Chenopodiaceae and mesophilous Gramineae were the most abundant. In addition, the value of nap/ap was low. Thus, we suggest that it was an open forest steppe ecosystem with a warm and humid climate.

From 4.4 to $3.5 \mathrm{Ma}$, the arboreal taxa composed of $\mathrm{Ul}$ mus and Betula, decreased slightly, and the subtropical species were few. The amounts of herbaceous taxa increased, and Nap/ap increased. Thus, the study area may have been covered by parklands, corresponding to drying conditions. Especially, during 3.9-3.7 Ma, desertic steppe plants belonging to the Chenopodiaceae increased notably, arboreal abundances were lower, and nap/ap values were the highest. As we know, Chenopodiaceae are particularly successful in dry, saline habitats of temperate and subtropical climates. These findings suggest that the vegetation structure may have changed to a desert steppe, and the climate may have undergone an increase in temperature and evaporation, with low rainfall conditions.

Since 3.5 Ma to 3.05 Ma, the dominant feature was the peak abundance of herbaceous species, including Artemisia, Gramineae, and especially Compositae. In addition, the desertic Chenopodiaceae decreased. The abundance of arboreal taxa decreased to their lowest point, including moderate arboreal plants such as Betula, Ulmus, Quercus, and coniferous taxa, such as Pinus. The subtropical indicatives disappear. The pollen assemblage suggests an open steppe vegetation landscape during this interval, and the climate appears to have been cool and dry.

During 3.05 Ma and 2.8 Ma, the abundance of arboreal taxa was slightly less than in stage one, and increased suddenly with Pinus and Ulmus. The herbaceous species decreased, such as Atemisia, Compositae, Gramineae, and Chenopodiaceae. Nap/ap decreased dramatically. The forest steppe during this period is suggested to have been that of a warm and moist climate.

\subsection{The strong East Asian summer monsoon before 3.5 Ma}

Under control of the EAM precipitation, the modern latitudinal vegetation patterns of the CLP were distributed as shown in Figure 1. Deciduous and evergreen forests existed in the southeastern plateau. As precipitation decreased to the north, ecosystems opened to forest-steppes, and then steppes and steppe-deserts. With the arboreal taxa declining, the EASM precipitation decreased to the north. Hence, arboreal abundances can be used to mirror the relative seasonal precipitation.

On the CLP, the combined temporal and spatial vegetation patterns may shed light on past climate systems. The pollen data of the Luzigou section is the most northerly vegetation record so far, which allows evaluation of latitudinal trends for the ecosystem evolution during the Pliocene. The limited previous published pollen data are restricted to the central and southern CLP, including red clay deposition sections, such as the Xifeng [14], Chaona [15], and fluvial deposition, such as Yushe [30] and Lingtai [31], covering the interval from $\sim 7 \mathrm{Ma}$ to $\sim 2 \mathrm{Ma}$.

The Yushe record shows that forest landscape dominated during 5.1-2.3 Ma. Before 3.5 Ma, the arboreal abundances ranged from $60 \%$ to $90 \%$. The mixed coniferous broadleaf 
forest developed, along with the occurrence of subtropical taxa, such as Carya. After 3.6 Ma, the grass expanded rapidly [30]. Lingtai data show that the percentage of arboreal taxa and shrubs was $91.4 \%$, with deciduous broadleaf trees at $37 \%$. The needle-deciduous forest mainly was composed of Pinus and Betula, which indicates that during 5.8-3.4 Ma, subtropical Carya and Tsuga also appeared [31]. During 5.6-3.7 Ma, the arboreal abundance of Chaona was $55 \%$. The pollen assemblage records the transition from the deciduous forest (made up of Quercus, Salix, Betula and Ulmus) to Cupressaceae forest habitats with increased seasonality at 3.7 Ma [15]. At Xifeng, the arboreal abundance was $24 \%$ before $3.7 \mathrm{Ma}$, and decreased to $11 \%$ after that time. The reduction of arboreal taxa indicates that the vegetation gradually changed from temperate forest plants to typical grassland after 3.7 Ma [14]. At the most northerly section of the Luzigou, the arboreal abundance was $24 \%$, and there were subtropical Rutaceae and Rhus surviving before 3.5 Ma. After that time, the arboreal trees decreased to $11 \%$. The pollen records suggest a vegetation transition from forest steppes to steppe landscapes at 3.5 Ma.

Conclusively, the pollen assemblages show high percentages of arboreal trees, and subtropical taxa surviving in most sections during 5.6-3.5 Ma. The pollen distribution features may demonstrate:

(1) The S-N humidity gradient. The S-N directional decrease of arboreal trees indicates that there may have been an S-N humidity gradient, similar to that of the modern monsoon state. The S-N directionality of this humidity gradient, drying northerly, may suggest the existence of summer monsoon-like climate regimes on the CLP for at least the past $6 \mathrm{Ma}$.

(2) The warm and humid CLP. The finding that more arboreal taxa developed over the entire CLP suggests a more humid climate, corresponding to a strong EASM condition.

Thus, we suggest that the CLP underwent a much warmer and more humid climate during 5.6-3.5 Ma. During this time interval, the EASM was strong, corresponding to the low ice volumes of the Early Pliocene [12]. This link between strong EASM and warm intervals at high latitude in the Northern Hemisphere agrees with the pattern that existed throughout the Pleistocene. Thus, the strengthened EASM driven by the global ice volumes appears to have existed during the Early Pliocene.

\subsection{Other evidence for paleoclimate change during the Pliocene}

The paleoclimate changes recorded from the Luzigou pollen data are consistent with many other proxies from the CLP. First, detailed investigations on N-S CLP transect sections by grain size and major element geochemical analysis demonstrate two cycles of the Pliocene Red Clay separated by $3.5 \mathrm{Ma}$, with a warm and stable state climate through most of the Pliocene time during the 5.3-3.5 Ma interval
[32]. From 3.5 Ma onward, the climate transition from warm and wet to cool and dry can be supported further by the molluscan fossil change from thermo-humidiphilous species to meso-xerophilous taxa of the Xifeng section [33]. Noticeably, the very recent molecular fossil studies from the Xifeng and Chaona sections in the CLP also show a transition from forest steppe to steppe ecosystem evolution at $\sim 3.5$ Ma during the Pliocene [34,35]. The $\delta^{13} \mathrm{C}$ from mammal fossils of the CLP also show the increase in $\mathrm{C}_{4}$ vegetation observed at the southern Loess Plateau localities during 4-2 Ma, and these correspond to the onset of strong winter monsoons [36]. During 5.7-5.48 Ma, the Miaoliang fauna with a high proportion of Cervidae, are characterized by high diversity and low dominance. This is the typical structure of forest-type faunas, indicating the warm and moist forests or forest steppe environments of the Early Pliocene. The Renjiapo fauna at 3.4 Ma mainly are composed of even-toed ungulates, with a predominance of hypsodont animals. Their signatures represent grassland expansion and a cool-dry climate $[37,38]$.

\section{Conclusions}

The pollen assemblages divided the paleo-vegetation of the Pliocene into four stages, at 4.4, 3.5, 3.05 Ma. The ecologic environment changed from forest to parkland to steppes, at last to forest steppes. In combination with other pollen data of the CLP, we identified the characteristics of the ecosystem before 3.5 Ma, with high percentages and S-N directional decreases in the arboreal taxa, which may indicate a much warmer and moister CLP and a strong summer monsoon condition.

We thank Wang Junping, Hu Xiaofei, Liu Quan, Long Liqun for their field work assistance. We are thankful to Prof. Pan Baotian and Wang Junping for providing the depth-age model of the Luzigou section. We also thank associate researcher Wang Luo for sharing pollen data of Xifeng. The first author thanks Prof. Xu Qinghai for assisting with pollen identification and Barnhart Laura for editorial improvements to the manuscript. This work was supported by the National Natural Science Foundation of China (40871098, 40771214 and 40920114001) and the Knowledge Innovation Program of the Chinese Academy of Sciences (KZCX2-YW-Q09-04).

1 Liu T S. Loess and the Environment (in Chinese). Beijing: China Ocean Press, 1985

2 An Z S, Kutzbach J E, Prell W, et al. Evolution of Asian monsoons and phased uplift of the Himalaya-Tibetan Plateau since late Miocene times. Nature, 2001, 41: 62-66

3 Guo Z T, Ruddiman W F, Hao Q, et al. Onset of Asian desertification by $22 \mathrm{Myr}$ ago inferred from loess deposits in China. Nature, 2002, 416: $159-163$

4 Ding Z L, Rutter N W, Sun J M, et al. Rearrangement of atmospheric circulation at about 2.6 Ma over northern China: Evidence from grain size records of loess-paleosol and red clay sequences. Quat Sci Rev, 2000, 19: 547-558

5 Bloemendal J C, Liu X M, Rolph T C. Correlation of the magnetic susceptibility stratigraphy of Chinese loess and the marine oxygen isotope record: Chronological and palaeoclimatic implications. Earth Planet Sci Lett, 1995, 131: 371-380 
6 Fang X M, Li J J, Banerjee S K, et al. Millennial-scale climatic change during the last interglacial period: Superparamagnetic sediment proxy from paleosol S1, western Chinese Loess Plateau. Geophys Res Lett, 1999, 26: 2485-2488

7 Kukla G. Loess stratigraphy in central China. Quat Sci Rev, 1987, 6: 191-219

8 Sun $\mathrm{X}$ J, Wang $\mathrm{P} \mathrm{X}$. How old is the Asian monsoon system?-Palaeobotanical records from China. Palaeogeogr Palaeoclimatol Palaeoecol, 2005, 22: 181-222

9 An Z S, Huang Y, Liu W, et al. Multiple expansions of $\mathrm{C}_{4}$ plant biomass in East Asia since 7 Ma coupled with strengthened monsoon circulation. Geology, 2005, 9: 705-708

10 Ding $\mathrm{Z} \mathrm{L}$, Yang S L. $\mathrm{C}_{3} / \mathrm{C}_{4}$ vegetation evolution over the last $7.0 \mathrm{Myr}$ in the Chinese Loess Plateau: Evidence from pedogenic carbonate $\delta^{13}$ C. Palaeogeogr Palaeoclimatol Palaeoecol, 2000, 160: 291-299

11 Jiang W Y, Peng S Z, Hao Q Z, et al. Carbon isotopic records in paleosols over the Pliocene in Northern China: Implication on vegetation development and Tibetan uplift. Chinese Sci Bull, 2002, 47: 687-690

12 Shackleton N G, Hall M A, Pate D. Pliocene stable isotope stratigraphy of ODP site 846. In: Pisias N G, Mayer L A, Janecek T R, et al. eds. Proceedings of the ODP Science Results, 1995,138: 337-355

13 Wara M, Ravelo A C, Delaney M L. Permanent El Nino-like conditions during the Pliocene warm period. Science, 2005, 309: 758-761

14 Wang L, Lü H Y, Wu N Q, et al. Palynological evidence for Late Miocene-Pliocene vegetation evolution recorded in the red clay sequence of the central Chinese Loess Plateau and implication for palaeoenvironmental change. Palaeogeogr Palaeoclimatol Palaeoecol, 2006, 241: 118-128

15 Ma Y Z, Wu F L, Fang X M, et al. Pollen record from red clay sequence in the central Loess Plateau between 8.10 and 2.60 Ma. Chinese Sci Bull, 2005, 19: 2234-2243

16 Xin Z B, Xu J X, Zheng W. Spatiotemporal variations of vegetation cover on the Chinese Loess Plateau (1981-2006): Impacts of climate change and human activities. Sci China Ser D-Earth Sci, 2008, 51: $67-78$

17 Cheng J M, Wan H. Vegetation Construction and Soil and Water Conservation in the Loess Plateau of China (in Chinese). Beijing: China Forest Publication Press, 2002

18 Zdansk O. Fundorte der Hipparion-Fauna umPao-Te-Hsien in NWShansi. Bull Geol Sur Chin, 1923, 5: 69-81

19 Teilhar D C, Youn C C. Fossils mammals from the Late Cenozoic of Northern China. Palaeontol Sin, Ser C, 1931, 9: 1-67

20 Editing Committee of the Baode County Annals. Baode county annals. Taiyuan: Shanxi People's Publishing House, 1990

21 Wang J P. Formation and Evolution of the Middle reaches of the Yellow river since Late Cenozoic. Dissertation for the Doctoral Degree. Lanzhou: Lanzhou University, 2006

22 Wu F L, Fang X M, Ma Y, et al. Plio-Quaternary stepwise drying of Asia: evidence from a 3-Ma pollen record from the Chinese Loess Plateau. Earth Planet Sci Lett, 2007, 257: 160-169

23 White J M, Ager T A, Adam D P, et al. An 18 million year record of vegetation and climate change in northwestern Canada and Alaska:
Tectonic and global climate correlates. Palaeogeogr Palaeoclimatol Palaeoecol, 1997, 130: 293-306

$24 \mathrm{Ke} \mathrm{M} \mathrm{H.} \mathrm{A} \mathrm{method} \mathrm{of} \mathrm{sporopollen} \mathrm{analysis} \mathrm{in} \mathrm{loess} \mathrm{(in} \mathrm{Chinese).}$ Acta Bot Sin, 1994, 36: 144-147

25 Wu F L, Fang X M, Miao Y F, et al. Environmental indicators from comparison of sporopollen in early Pleistocene lacustrine sediments from different climatic zones. Chinese Sci Bull, 2010, 55: 2981-2988

26 Li X Q, Zhou J, Ashr A R, et al. A new way of sporopollen analysis in Loess deposits: Sieving-analysis method (in Chinese). J Des Res, 1999, 19: 399-402

27 Sun X J, Wang F Y, Song C Q. Pollen-climate response surfaces of selected taxa from Northern China. Sci China Ser D-Earth Sci, 1996, 39: 486-493

28 Wang F Y, Song C Q, Sun X J, et al. Climatic response surface from pollen data for four arboreal taxa north China (in Chinese). Acta Bot Sin, 1997, 39: 272-281

29 Zhao J B, Yue Y L, Yue M. A study on the sporeopollen assemblage of modern oak forests in Qinling Mountains and loess area (in Chinese). J Xi' an Eng Univ, 1998, 20: 46-50

30 Shi N, Cao J X, Lars-Konig K. Late Cenozoic vegetational history and the Pliocene-Pleistocene boundary in the Yushe basin, S E Shanxi, China. Grana, 1993, 32: 26-271

31 Wu Y S. Palynoflora at Late Miocene-Early Pliocene from Leijiahe of Lingtai, Gansu Province, China (in Chinese). Acta Bot Sin, 2001, 7: $50-56$

32 Han J T, Chen H, Fyfe W S, et al. Spatial and temporal patterns of grain size and chemical weathering of the Chinese Red Clay Formation and implications for East Asian monsoon evolution. Geochim Cosmochim Acta, 2007, 16: 3990-4004

33 Wu N Q, Pei Y P, Lü H Y, et al. Marked ecological shifts during 6.2-2.4 Ma revealed by a terrestrial molluscan record from the Chinese Red Clay Formation and implication for palaeoclimatic evolution. Palaeogeogr Palaeoclimatol Palaeoecol, 2006, 233: 287-299

34 Bai Y, Fang X M, Nie J S, et al. A preliminary reconstruction of the paleoecological and paleoclimatic history of the Chinese Loess Plateau from the application of biomarkers. Palaeogeogr Palaeoclimatol Palaeoecol, 2009, 271: 161-169

35 Liu W G, Zhang P, Sun Y B, et al. Molecule fossil evidence for paleovegetation changes in the central of Chinese Loess Plateau during 7-2 Ma-Zhaojiachuan profile as an example (in Chinese). Quat Sci, 2008, 28: 806-811

36 Passey B H, Ayliffe L K, Kaakinen A, et al. Strengthened East Asian summer monsoons during a period of high-latitude warmth? Isotopic evidence from Mio-Pliocene fossil mammals and soil carbonates from northern China. Earth Planet Sci Lett, 2009, 277: 443-452

37 Zhang Y X, Sun D H, An Z S, et al. Mammlian fossils from late Pliocene (Lower MN 16) of Lingtai, Gansu Province (in Chinese). Vertebrata PalAsiat, 1999, 27: 190-199

38 Xue X X, Zhang Y X, Yue L P. Paleoenvironments indicated by the fossil mammalian assemblages from red clay-loesssequence in the Chinese Loess Plateau since 8.0 Ma B P. Sci China Ser D-Earth Sci, 2006, 49: 518-530

Open Access This article is distributed under the terms of the Creative Commons Attribution License which permits any use, distribution, and reproduction in any medium, provided the original author(s) and source are credited. 